\title{
Industrial Location and Global Restructuring in Australian Cities
}

\author{
Thomas J Sigler $^{1}$, Glen Searle ${ }^{1}$ and Kirsten Martinus ${ }^{2}$ \\ Australian Geographer Special Issue 'Globalising the Australian Economy'
}

\begin{abstract}
:
Globalisation has impacted both the balance of economic power between cities as well as the distribution of economic activities within them. Studies focussing on the impacts of globalisation often investigate one or the other, but rarely tie the two together. In Australian cities, CBDs and inner suburbs since the 1980s have become revalorised as strategic sites for multinational firm activities, complementing an already robust agglomeration of commodities-oriented firms, domestic manufacturing, and state-led industries. This paper compares the spatial organisation of Australian firm activity across Perth, Brisbane, Melbourne and Sydney. It first focusses on how the firms of each of these cities extend overseas through global branch office operations, and then shifts to the distribution of firms within each capital city region. Data are drawn from a complete set of 2196 listed Australian Securities Exchange (ASX) firms with operations in more than 100 countries. We find that while the mix of industries differs significantly between cities, the overall industrial patterns observed are relatively consistent from one city to the next. Australian cities are economically fairly centralised and services-oriented industries in particular are most prominent within central business districts. Sydney's firms are found to be the most globalised, although all cities have significant numbers of global firms. We also find that locational requirements are significantly varied from one industry to the next and between firm headquarters and branches. This has implications for planning cities to meet firm requirements in an economy that is digital and globally connected, and for national-level policy that distributes core economic competencies amongst Australian cities.
\end{abstract}

Keywords: Urban Geography; Economic Geography; Industrial Geography; Spatial Analysis; Corporate Headquarters; Australia

Running Header: Comparative analysis using firm headquarters and branch office locations

${ }^{1}$ School of Earth and Environmental Sciences, University of Queensland, Brisbane, Queensland 4072 Australia

${ }^{2}$ Centre of Regional Development, University of Western Australia, Perth, Western Australia 6009 Australia 


\section{Introduction}

Globalisation has had transformative impacts on urban form and the economic structures within cities, with a number of economic, social, demographic, and political pressures acting to reorder space relationally (Massey 2005). Though the conditions are also highly contextual and contingent upon path-dependent local processes, urban spaces have been transformed to varying degrees by the concomitant outcomes of gentrification (Smith 2002), financialisation (Rutland 2010), urban renewal (Hansen et al. 2001), neoliberal politics (Randolph \& Tice 2014), and the growth of the transnational corporation.

Since the 1980s, urban economic change has been studied extensively by analysing the activities of large numbers of transnational corporations (Sassen 2001), whose geographic scope extends across space through specific global city networks (Taylor et al. 2006). And while transnational firms were initially conceived of as state-based entities that actively 'globalised' by penetrating into new territorial markets (Dicken 1988; Friedmann 1986; Hymer 1976), global production networks (Henderson et al. 2002) and supply chains (Gereffi et al. 2005) now traverse borders to an extent that renders 'domestic' and 'international' firms virtually indistinguishable.

A strong case exists that Australian cities have been historically more globalised than many other contexts (Sandercock 1990; Rennie-Short 2004). Initially dependent on colonial ties linked to commodity exports, the Australian economy is, and has fundamentally been, articulated through its cities as administrative hubs and as entrepôts for flows of goods and services (cf. Tonts et al. 2013). Both the internal structure of Australian cities, as well as the firms and institutions within them, are therefore inextricably linked to global circuits of capital, resources, and migration. Despite this, the Australian spatial economy has historically been framed through a 'domestic' methodological lens (Cashdm 1995; Stilwell 2005). This literature often takes inter-state relativities as its focus (e.g. Connolly and Lewis, 2010), and most studies of Australian economic development simply focus on the national level (e.g. Halevi \& Kriesler 1991; Downes et al. 2014). The role of cities in shaping global flows and vice versa is, for example, conspicuously absent from Fagan and Webber's Global Restructuring (1994), which is the focus of this special issue. This oversight perhaps drew on 
underlying contemporary assumptions regarding the largely generic and passive nature of Australian cities whose centralised structures were essentially the result of the loss of manufacturing and shift to agglomeration economy industries of communications, finance and business (Hamnett \& Freestone 2000). And although cities are tacitly acknowledged in the literature on neoliberal shifts in the global economy (O’Neill \& Fagan 2006), the 'urban agenda' literature has remained relatively disconnected from wider global economic flows and relationships in terms of how transportation, planning, and related issues are framed (Dodson 2005, 2009; Steele \& Gleeson 2010; Shaw 2013).

This paper examines the distribution of publically-traded firms by industry across the four largest Australian city-regions in order to better understand how economic configurations shape urban form and structure, and how globalisation in turn shapes the nature of industry. It first explores the role of globalisation in Australian cities, concentrating on the degree to which industry composition is reflective of how global processes are embedded within urban spatial structure. It then turns attention to a detailed city-by-city analysis of the distribution of firm activity by headquarters and branch office locations, focussing on a number of indicative firms that capture the globalisation strategy of dominant industries within Australia's four largest cities.

\section{Data and Methods}

This research employed a dataset of 2,196 Australian Securities Exchange (ASX) registered and actively traded firms as of mid- $2016^{1}$ to compile a list of all directly-owned firm headquarters and branch office locations. Retail or sales offices (e.g., bank branches) as well as affiliated or jointlyowned firms (i.e., subsidiaries and joint ventures) were excluded.

Of the total 4,307 ASX office locations throughout Australia and internationally, there were 1,864 in Perth, Brisbane, Melbourne or Sydney, the four largest Australian city-regions (Greater Capital City Statistical Areas or GCCSAs). Though the vast majority of ASX headquarters were located within Australia (92\% of the total), with $85 \%$ of firms and $86 \%$ of market capitalisation (the aggregate sum of firms' value) within the four GCCSAs, many of the branches were located in regional areas and overseas, with offices across 127 countries and territories. Offices were categorised according to ASX industry sectors based on the Global Industry Classification Standard (GICS); these

\footnotetext{
${ }^{1}$ The initial set of firm headquarters was retrieved in June 2016, and branches were collected over the subsequent months. The dataset therefore represents an idealised corporate list, as shares are traded on a daily basis, and take-overs, mergers, acquisitions, and insolvency would affect firms' status as 'actively traded'.
} 
11 sectors are classified into 24 industry groups. For visualisation purposes, these were further collapsed into five designated macro-categories (Table 1).

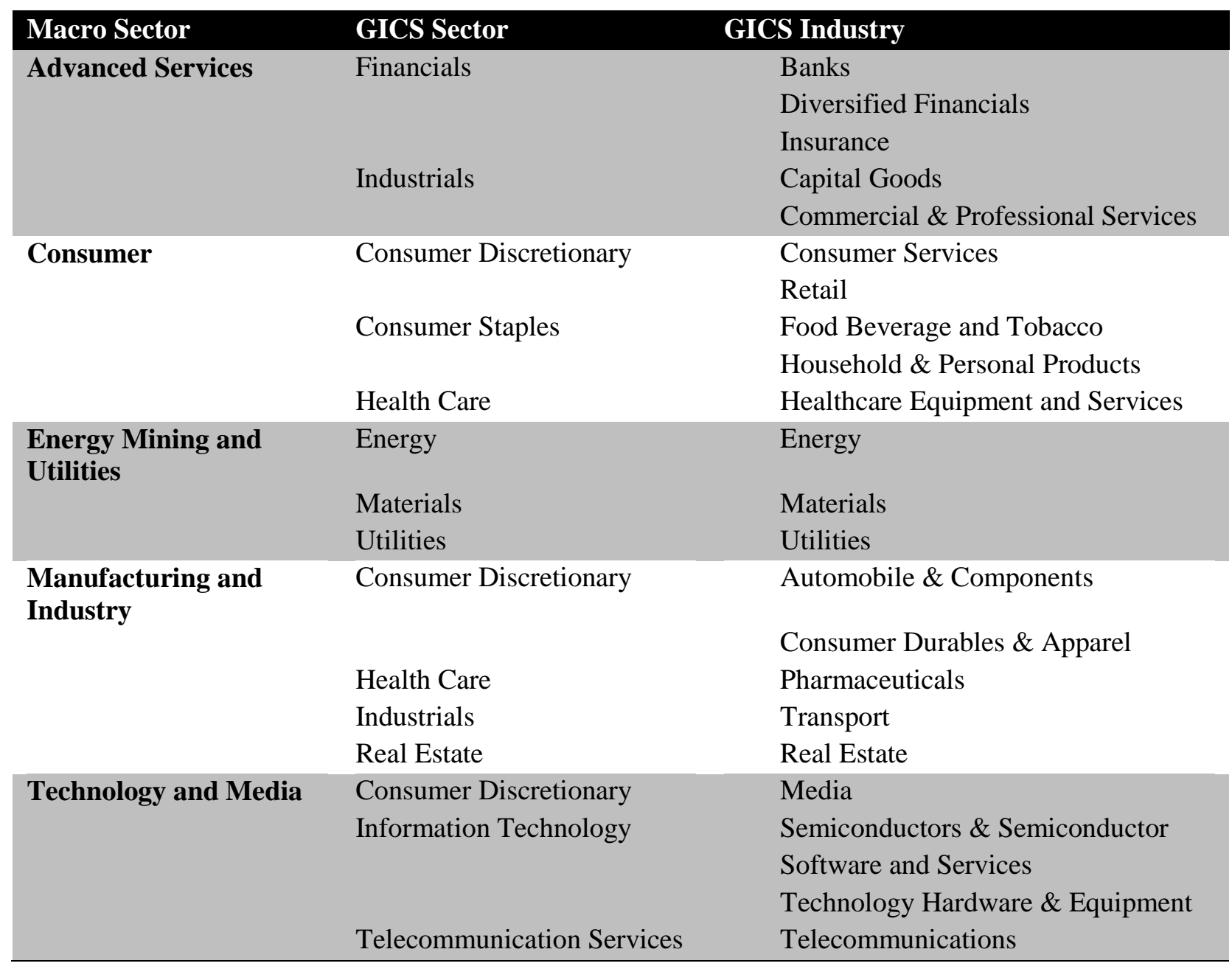

Table 1. GICS Sector and Industry Structure with Macro-Industry (Proprietary) ${ }^{2}$

Firm office locations were geocoded to discrete points, and spatially joined within Statistical Area Level 3 (SA3) boundaries, which the Australian Bureau of Statistics (ABS) defines as a medium-scale spatial unit. By examining the distribution of firms by industry and location, the footprint of industrial sectors were unpacked to understand the dynamics of each GCCSA. Spatial analysis was followed by descriptive analysis seeking to explain the patterns in each city with respect to individual urban histories, planning schemes, and geographies.

\footnotetext{
${ }^{2}$ Only listed and traded firms with identifiable office locations were included.
} 


\section{Globalisation and the Economy of Australian Cities}

Unlike many parallel contexts, Australian state capitals serve as both the commercial and political/administrative loci of their respective states, rather than just one or the other. Until the Australian financial system was deregulated and became integrated with the emerging global system in the early 1980s, the economies of the major cities were largely structured as part of a relatively closed national economy that had evolved from separated colonial/state economies with the capital cities as their focus (Gibson \& Horvath 1983).

Thus from the time of settlement to the decades after Federation (in 1901), globalisation generated rail and port activity centred on exports of resources and imports of manufactures, creating strong centralisation around what are now state capital cities. The states (initially colonies) drew British finance to develop infrastructure, including the rail lines used to export wool and wheat, while local banks grew by financing the exporting farmers and graziers (Holder 1970). The expansion of the agricultural and mining sectors via exports, and of related commercial activities in the nation's towns and cities, drew in large numbers of immigrants during the nineteenth century, especially to work in new goldfields. The expansion of domestic manufacturing behind tariff walls after Federation (Rich 1987) produced new global impacts. Overseas consumer goods multinationals brought investment in to establish local branch plants, mostly in the cities, and after 1945 a surge of immigrants came in to work in the factories and in other jobs generated by rapid population increase. This produced city economies that were relatively undifferentiated except for proactive state-led industrialisation in Adelaide and, to a lesser extent, Melbourne. Even global manufacturing investment was spread among the capitals, with the five biggest cities each having a General Motors manufacturing or assembly plant and an oil refinery at one stage.

From the early 1980s, this national structure started breaking down: local production became less economically feasible as tariffs on imports decreased under the General Agreement on Tariffs and Trade (GATT), along with declining international communication and transport costs, and investment became more mobile across the globe. Manufacturing by local and international firms declined. The finance sector grew by closer linkages to global circuits of capital, importing overseas funds to finance residential and other construction, and trading international currencies and various other financial instruments. There were booms in the mining, oil and gas sectors in the 1970s and early 1980s, and another boom from 2005 to 2012 linked to key commodity exports such as iron ore and the concomitant capital investments these attracted. These booms generated backward linkages 
especially in the major cities, and provided the basis for resource services companies in Perth, Brisbane and other cities to compete in global markets with overseas production and distribution outlets, while mining leaders such as BHP became major multinationals with extensive overseas operations. Cities were now seen as being in competition with one other to attract global investment, and state policies started to focus on attracting mobile global economic activities and investment to their capitals (Searle 2002). This explains 'globalising' policy such as Sydney’s 'Global City' agenda vis-à-vis its discursive 'global arc', and the recent 'Brisbane: Australia's New World City', which curate portfolios of public support for globally focussed commercial activities.

From a firm perspective, there are several ways one can observe the globalisation of Australian cities since approximately the early 1990s, when Global Restructuring was written. Firms have had to adapt to widespread liberalisation, which was in large part driven by a series of deregulatory measures aimed at enhancing productivity and competitiveness, and extending international markets beyond those developed through Commonwealth linkages with the UK and former British colonial world (e.g. Canada, New Zealand, Singapore, United States). This revalorised cities as strategic sites of firm competitiveness, meaning that firm location was critical to success. This translated into large-scale investments in commercial property in the form of office towers, specialised business parks and mixed-used developments, particularly in Sydney and to a lesser extent in Melbourne. As Berry and Huxley (1992) observed, the 'massive switch of capital into the Australian built environment over the past decade has been managed by an increasingly sophisticated and internationalised financial sector, selectively deregulated by the federal government' (p. 37).

Multi-scalar governance (i.e. federal, state, and local) has further shaped the distribution of firms both within and between cities by supporting existing agglomeration through infrastructural investments as well as a business-friendly institutional environment in which developer and infrastructure lobby groups and pro-business city committees have made the case for public intervention to boost the development of cities and favoured areas within them. Uniform provision of public facilities and infrastructure has been substantially replaced by spatially selective provision of infrastructure by public-private partnerships or privatised public authorities in locations that maximise profits or investment gains generally (c.f. Brenner 2004; Graham \& Marvin 2001). Governments have contracted out many of their activities, emphasising cost reductions. The town planning regulatory environment has loosened former tight restrictions on where development activity could be located, with greater designation of mixed use zones and higher density areas, together with more state powers to overturn local government control of development (Searle and 
Bunker 2010; Gurran 2011; Ruming and Gurran 2014). These institutional trends have provided new location opportunities for economic activity but also added uncertainty to firm location choices.

While much literature associates globalisation with the expansion of advanced producer services (Sassen 2001; Taylor et al. 2006), Australia has globalised largely through resources (Tonts et al. 2013) and the export of related services. Service exports, mainly education and tourism, comprise just 22 percent of all exports (DFAT 2017b). The demand for advanced producer services in Australia is primarily domestic in that major exports are raw materials such as iron ore, coal and natural gas (DFAT 2017a), which tend to draw on intermediate service inputs (or 'embodied services' in the final good that is exported) such as sales, logistics and business services as a means to ensure competitiveness in the global market. Furthermore, much of advanced service sector activity in Australia is consulting to government (local, state or federal), which makes the public sector a key driver of service demand.

\section{The Distribution of Sectors across Australian Cities}

Taking these defining aspects of the Australian economy into account provides an understanding of how similar or complementary industry sectors cluster at different locations within the four Australian cities of this study. Such understandings speak more broadly to how the processes of globalisation have influenced the development of Australian cities and the way the economy is connected at intraand inter-national scales. This means there will be industry differences between cities, as well as within the different locations of the same city. Indeed, research by O'Neill and McGuirk (2005), Searle (1996, 2008), and O'Connor (2002) confirms that Sydney and Melbourne house the largest number of Australian firms listed and operating overseas offering advanced services. Further, Sigler (2013) found that Perth is more attractive to corporations than previously assumed, albeit these are largely small firms engaged in its global mining and energy operations (Martinus et al. 2015). Figure 1 offers a breakdown of the significance of each sector by city across ASX offices within Australia. 


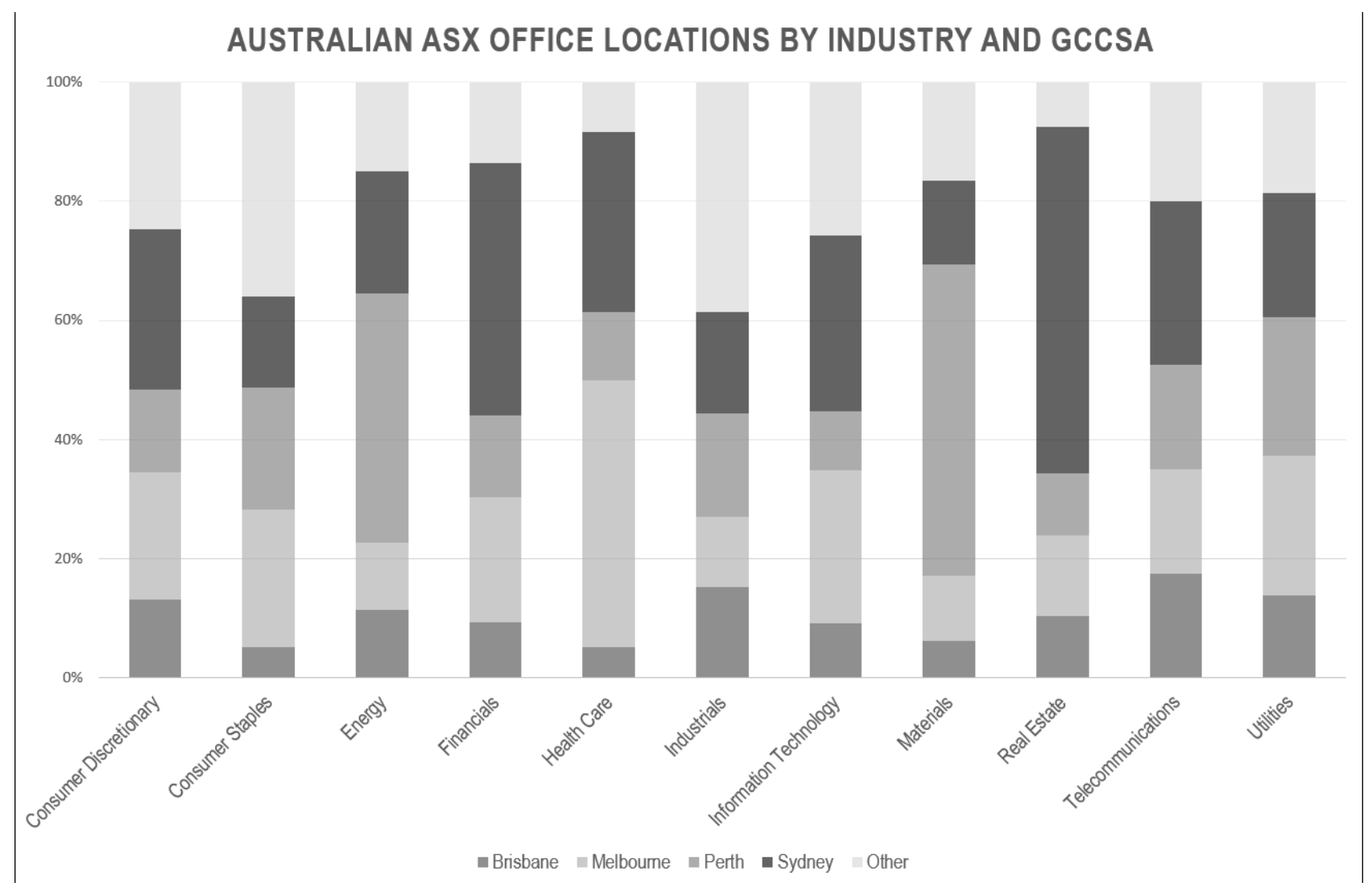

Figure 1. Office Locations by Sector across four Australian GCCSAs

Specialisation within GCCSAs becomes immediately clear within Figure 1. Sydney dominates the financials sector, and hosts a large number of offices in information technology, real estate, and telecommunications - all being advanced services related to the city's fiduciary agglomeration. Melbourne's strength lies in health care, which is tied to its position as national capital and former location of the Commonwealth health department, and to a slightly lesser extent in information technology and consumer goods. Perth's role in the energy and materials sectors stands out, and as past research has shown is the driving force in its urban economy despite the fundamentally regional nature of mining (Martinus and Sigler 2016). However, these differences are not the main focus of this paper.

Though the degree to which each city's economy is globalised is contingent upon its broad sectoral distribution, the depth of specialisation within particular sectors and industries is perhaps the key determinant (Tonts and Taylor 2013; Tonts and Taylor 2010). As Figure 2 shows, the industries that are the most global across the cities (consumer discretionary and materials) are somewhat distinct from the most dominant industries overall (financials, health care, consumer staples, utilities and 
telecommunications), reflecting a rough dichotomy between the two sets. Indeed, counter to the assumptions of much 'global cities' literature (Derudder et al. 2010), advanced producer services in Australia were not the most globalised, with the vast majority of financials and real estate firms domestically oriented. This aligns with observations that the services primarily deliver to other 'globalising' sectors of the economy - namely resources.

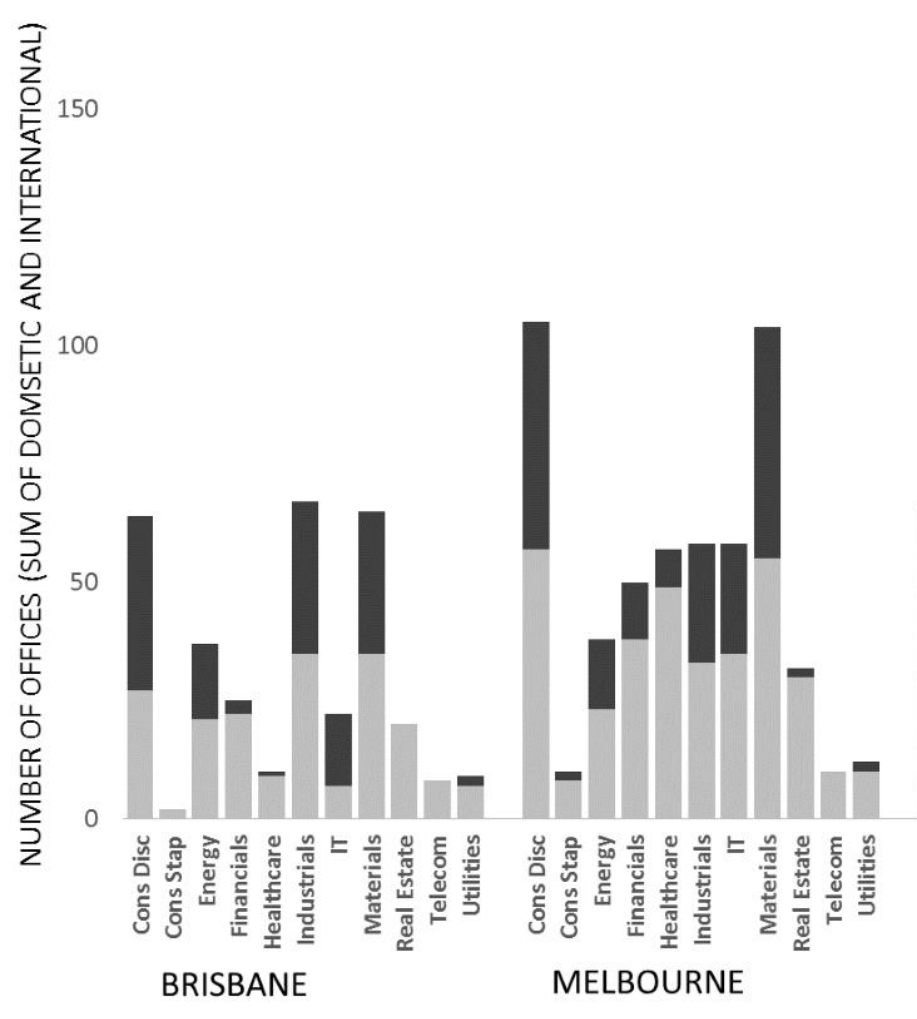

NUMBER OF INTERNATIONAL FIRM OFFICES IN DARK GREY

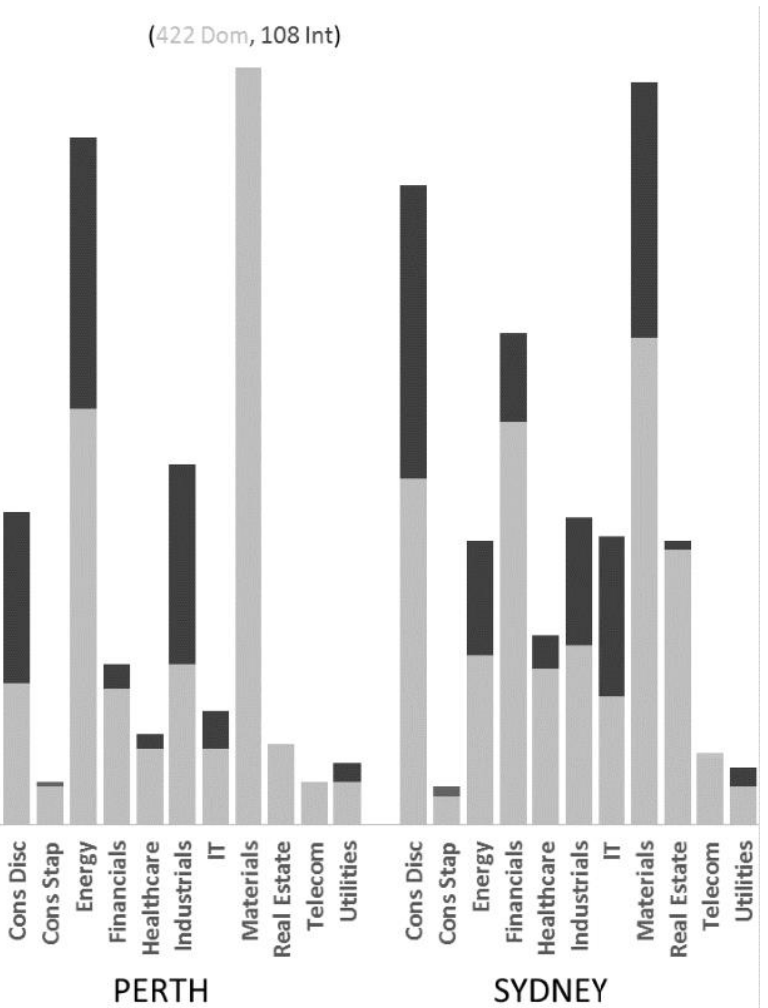

NUMBER OF DOMESTIC FIRM OFFICES IN LIGHT GREY

Figure 2. ASX Firm Offices (Headquarters and Branches) by City, Sector, and Internationalisation

Sydney and Melbourne have the most diversified sectoral base, but despite their 'global' city brand, Perth has the most domestic-oriented and international firms (678 and 264 firm headquarters respectively). Sydney's global firms (236 firms) lie in the consumer discretionary, industrials, IT, and materials sectors. Melbourne's globalisation (186 firms) was driven by a similar distribution of sectors, with a diminished role for financials and IT. Perth is most globally oriented in materials, industrials, and energy, and to a lesser degree industrials, and Brisbane is specialised in industrials, consumer discretionary, and materials, however with many fewer firms. 
Aside from the distribution of firm activity across industries and sectors within cities, the global extent of firms headquartered in each city provides a good overview of the command functions of each. This distribution is slightly different than the intra-urban sectoral mix, as headquarters locations have distinct locational requirements to branch offices (Sigler et al. 2016), and command functions are more likely to occur in large Australian cities than branch operations, especially as many overseas branches are sales offices and/or located near production facilities. As Table 2 shows, not only is the branch network of Sydney-based headquartered firms the most internationalised, it is also the most extensive network of all the Australian cities. This emerges from the vast global remit of its 1,020 international branch offices, or 77 per cent of the total, over 93 countries and territories ${ }^{3}$.

\begin{tabular}{|lrrr|} 
& Total Number & Overseas Number & Overseas Proportion \\
\hline Brisbane & 258 & 146 & $57 \%$ \\
Melbourne & 434 & 200 & $46 \%$ \\
Perth & 214 & 139 & $65 \%$ \\
Sydney & 1318 & 1020 & $77 \%$ \\
All Other Australia-Based & 160 & 40 & $25 \%$ \\
\hline
\end{tabular}

Table 2. The Globalisation of Branch Offices by Headquarters City

All four cities, however, are far more globally connected than the firms located than the country at large, and the connectivity of each city demonstrates that their respective global connections are firmly tied to dominant industries and respective inter-urban ties. Melbourne follows Sydney in terms of the expanse of its branch network, with Melbourne-based headquarters having branch offices in 53 countries, most of which are associated with large mining multinationals such as BHP, Orica, and Rio Tinto. Brisbane-based ASX firms have branches in 34 countries, and show a clear Asia-Pacific orientation driven by the industrials and energy industries. Brisbane also plays a regional role with corporate links to the Pacific islands on Australia's northern and eastern sea borders, the majority tied to firms involved in Queensland's energy and mining industries (Sigler and Martinus, 2016). And although Perth has the largest number of ASX-listed headquarters of all Australian cities, many are small firms with one or no branches, making the extent of its global reach (into 49 countries) similar to that of Melbourne and Brisbane. With the majority of international branch offices linked to local mining and energy companies, such as Woodside, Perth firm's branch offices are notable for their presence in Africa (South Africa, Ghana) and other nations associated with significant global

\footnotetext{
${ }^{3}$ Dependencies such as Guernsey and Hong Kong are counted separately.
} 
materials and energy exploration and production (Brazil, UAE) and consumption (South Korea, Japan).

\section{Urban Spatial Structure}

If the sectoral differentiation between Australian cities reveals how globalisation has impacted cities on a national scale, the geographical distribution of firms within them is instructive of the impacts of globalisation on a finer urban scale. Firm locational choice is a reflection of strategic economic advantage, with most empirical work stressing how firms co-locate with similar or complementary industries (Bathelt et al. 2004; Fujita \& Thisse 2013; Porter 2000). Though locational decisions are most often made on a firm-by-firm basis, broader industry and sector-based trends reveal intra-urban geographical patterns that situate firms strategically within a particular institutional or corporate ecosystem (Polèse \& Shearmur 2004). Irrespective of whether firms operate in global or domestic markets, locational strategies are determined by factors including access to local labour pools, resources and capital, and technological (Le Bas \& Sierra 2002) or informational advantage (Porter \& Millar 1985). Access to clients and novel ideas vis-à-vis proximity to vibrant urban centres may also be paramount to information-intensive industries, 'prestige' addresses and access to clients to professional services, and key political and business decision-makers to firms in the energy and resource industries. Industries creating disamenity (e.g., smokestacks, heavy truck traffic) are guided by planning to the metropolitan fringe, or to designated industrial corridors within the metropolitan region (e.g. inner-eastern Perth; inner-western Sydney). As such, the locational strategies of firms are determined by a unique set of factors related to the competitiveness of a 'place' to specific industries and the operational needs of a business.

Although Australian cities can be considered large and sprawling by global standards (Davison 2006), highly centralised governance structures have underwritten transportation infrastructures and maintained planning controls largely preserving the strength of central business districts (CBDs) in commercial functions (Forster 2006). In contrast to many other contexts, Australian cities have not developed the 'edge cities' and peripheral commercial nodes to the same extent as North American cities (Freestone \& Murphy 1998; Pfister et al. 2000). The degree of firm centralisation in Australian cities is partly determined by industry-both Watkins (2014) and Sigler et al. (2016) argue that centralisation is most vital to advanced producer services and related 
'knowledge' economy industries, whereas 'heavy' industry and consumer-oriented activities are more prone to dispersal as they seek lower land costs, in particular.

The following sections provide detailed maps of Australia's largest cities of Perth, Brisbane, Melbourne and Sydney by GCCSA of firm locations for 11 sectors and 24 industries at the Australian Bureau of Statistics (ABS) Statistical Area 3 (SA3) level. This level of aggregation was used to provide a more nuanced understanding of the patterns of firm locations found across the four metropolitan areas studied by headquarters and branch office locations. The patterns that emerge reveal the relative centralisation of each sector, as well as how globally exposed sectors are embedded within urban spatial structures.

\section{Perth}

Perth has the highest number of listed corporate headquarters (HQ) in Australia. The 675 HQ locations are mainly in materials (394) and energy (90), reflecting the dominance of the resources industry in the Western Australian economy. These company headquarters strongly connect Western Australia to other resources-driven economic hubs, with 25 Perth-listed headquarters having branch offices in Brisbane and 12 in Johannesburg, for example. HQ locations are highly centralised in the CBD and adjacent West Perth and Subiaco (Figure 3). This centralisation of materials and energy head offices is attributable to several factors. These include the greater proximity to other resource firms with similar labour and technology needs; access to Western Australian government policymakers and key business decision-makers given the large role policy and government plays in enabling resource exploration and production; and the benefits of co-locating with financiers, business specialists (e.g., accountants) and resource services firms due to the higher outsourcing requirements of the generally smaller Perth companies (with a high number of junior miners). As a result, these business service-related sectors are in turn relatively centralised, confirming that Perth follows the CBD-concentrated spatial employment patterns of other Australian and international cities for this industry sector.

In general, HQ offices beyond the central metropolitan area are in three types of locations. The first are prestigious CBD-adjacent office locations of South Perth and the so-called 'Golden Triangle' inner/middle area of Cottesloe-Claremont. The second are in more affordable office spaces close to the CBD in northern middle-ring area of Stirling (Osbourne Park commercial area), with a diversity of construction, manufacturing and resource industries, as well as eastern middle-ring areas of Belmont and Swan (Malaga) in the east offering larger warehousing and manufacturing spaces 
close to the airport. These identify large commercially-zoned parks where manufacturing facilities and depots are co-located with corporate functions. The location of listed company branch offices is similarly centralised. However, in the outer metropolitan regions, they are predominantly in large industrial areas rather than concentrated in suburban activity centres meaning they are more dispersed then HQs, particularly in the industrials and consumer discretionary sectors.

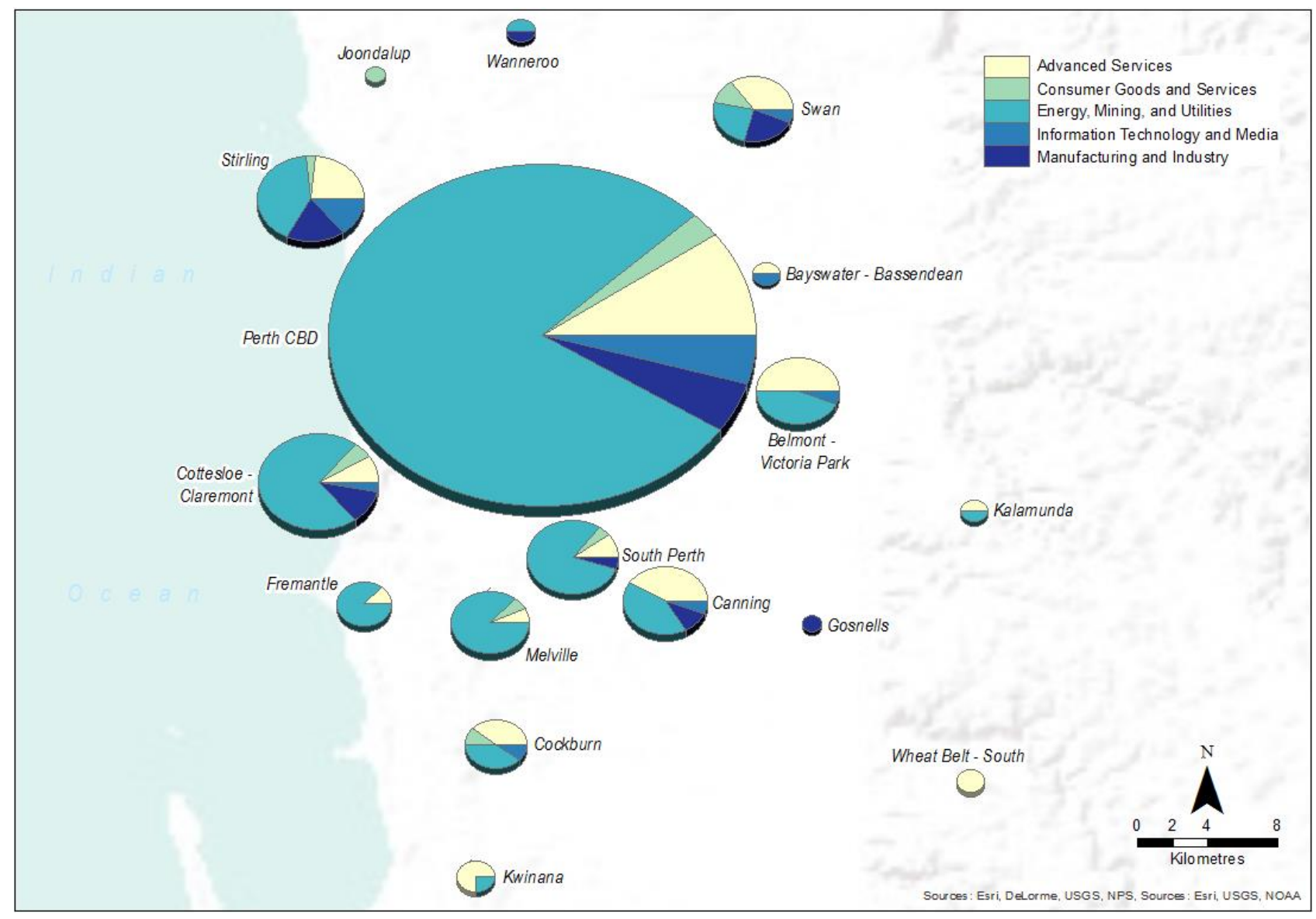

Figure 3. Perth Firm Headquarters and Branches

\section{Brisbane}

Brisbane has a significant number of listed HQ offices (245) across a range of sectors, notably industrials (60), materials (47), and consumer discretionary (33). The number and composition of these firms reflects the city's strong connectivity to the state's energy and materials centres (with numerous branches in the smaller Queensland cities of Townsville, Mackay and Gladstone). HQ locations (Figure 4) are fairly centralised. The main concentration of firm HQs is in the CBD, followed by the CBD fringe suburbs of Toowong and Milton to the west and Fortitude Valley to the 
east. These peri-central areas have good rail access for employees, supportive office zoning as well as easier on-site parking and cheaper rents than the CBD. While regional planning for Brisbane encourages the dispersal of offices in outer sub-regional centres, the concentration of the subsidised public transport system, advanced producer services, government and other HQs within the CBD provides competitive advantage making it difficult for most firm HQs to move to outer metropolitan locations. For example the HQ of Ausenco - an engineering company providing consulting, project delivery and asset management solutions to the resources, energy and infrastructure sectors across a number of countries - is located in South Brisbane adjacent to the CBD, which gives it good access to metropolitan professional labour pools and to mining and other client companies with HQs in and near the CBD. Linc Energy, an energy company specializing in international oil and gas production, has its HQ in the CBD, which maximises access to other companies it needs for exploration, production infrastructure and transport and sale of oil and gas, and access to 'buzz' about the energy sector amongst the firms of the nearby 'Golden Triangle' of Brisbane.

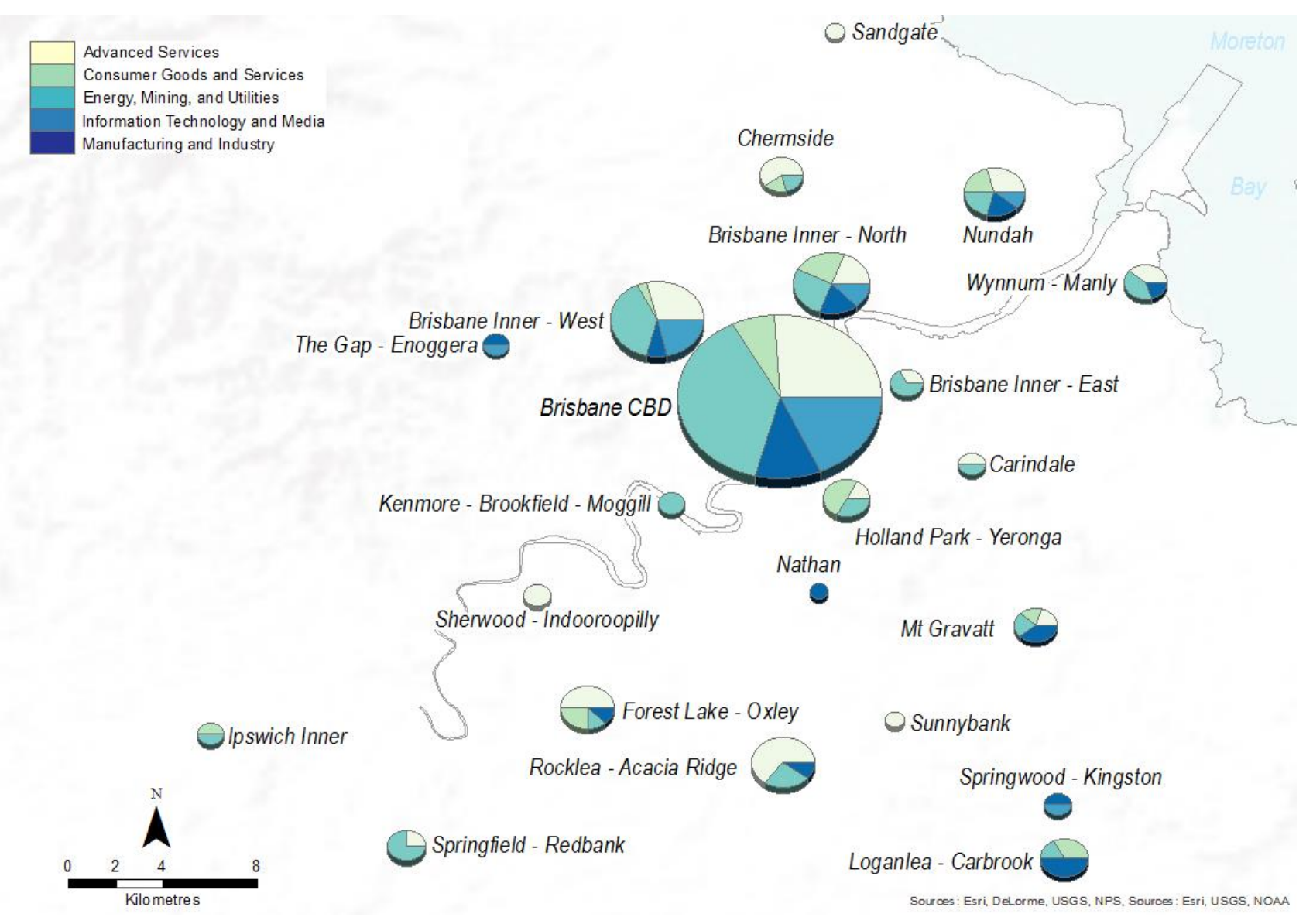

Figure 4. Brisbane Firm Headquarters and Branches 
The locational pattern for branch offices is also concentrated in the CBD, but with relatively more dispersal in fringe precincts. Materials and consumer discretionary branches in industrial areas in the south and south-west, as well as in the port/airport industrial zones in the east, reflect the location of associated manufacturing and depots. Energy branches are more centralised than energy HQs, possibly reflecting the need of the energy industry in general to have a high degree of strategic access to government, advanced finance, legal and consulting services for Queensland's significant coal and gas sector. Industrials branches show a similar level of relative centralisation to industrial headquarters, reflecting the spread of Brisbane's industrial precincts throughout the Metropolitan area - across the north but mainly across industrial areas to the east (Murrarie), south (RockleaArcherfield) and southwest (Oxley-Darra).

\section{Melbourne}

Melbourne is home to 393 ASX firm HQ offices. The main sectors of the listed firms are materials (80 firms), consumer discretionary (54), industrials (53) and health care (48). The large number of HQs highlights Melbourne's strong national economic role. This stems from its historical status until the 1960s as Australia's leading commercial centre and position within the Commonwealth of Nations. The location of firm HQs (Figure 5) is primarily concentrated in the CBD, northern CBD fringe and the St Kilda Road (South Melbourne) precinct. Primary industries are in real estate, health care, materials, industrials, with lesser number of firms in other sectors. In general, energy and financial HQs are the most centralised, and information technology HQs slightly more dispersed. Orica, a multinational company in the energy/mining/utilities category that makes mining chemicals and provides mining services, reflects the centralised HQ pattern of this sector with its head office location adjacent to the CBD in East Melbourne.

In addition, HQ concentrations are found in the high-status inner eastern suburbs around Hawthorn, specially-zoned office parks further out (as in Knox) (Seamer, 2014), followed by smaller clusters in industrial zones, especially in the south-east and west of the city. The overall easterly bias in HQ locations reflects in part the locational competitiveness of eastern suburban centres such as Box Hill through Melbourne's metropolitan centre planning policies countering rising CBD rental costs since the 1980s. It also reflects accessibility to the main concentration of professional and managerial labour in Melbourne. Illustrating this is Hansen, an IT company providing customer care 
and billing solutions to energy, utilities, pay TV, and telecommunications industries in seven overseas countries as well as Australia, which has its HQ in Doncaster the eastern suburbs as well.

Melbourne branch offices show a similar but slightly more dispersed pattern to HQs. In particular, there are numerous branch offices in industrial areas in middle and outer suburbs, where interaction with other firms and/or institutions is perhaps less important than cheaper land and/or proximity to industrial sites, and as older inner-city manufacturing sites become more valuable for alternate uses such as higher density residential development. Cardia, which makes resins for packaging or plastic products and which has overseas branches, is illustrative: its HQ, research centre and factory are in Mount Waverley in the outer south east. Similarly Nufarm, which makes agricultural chemicals in Australia and Europe, has its HQ alongside a factory at Laverton North, in Melbourne's outer west.

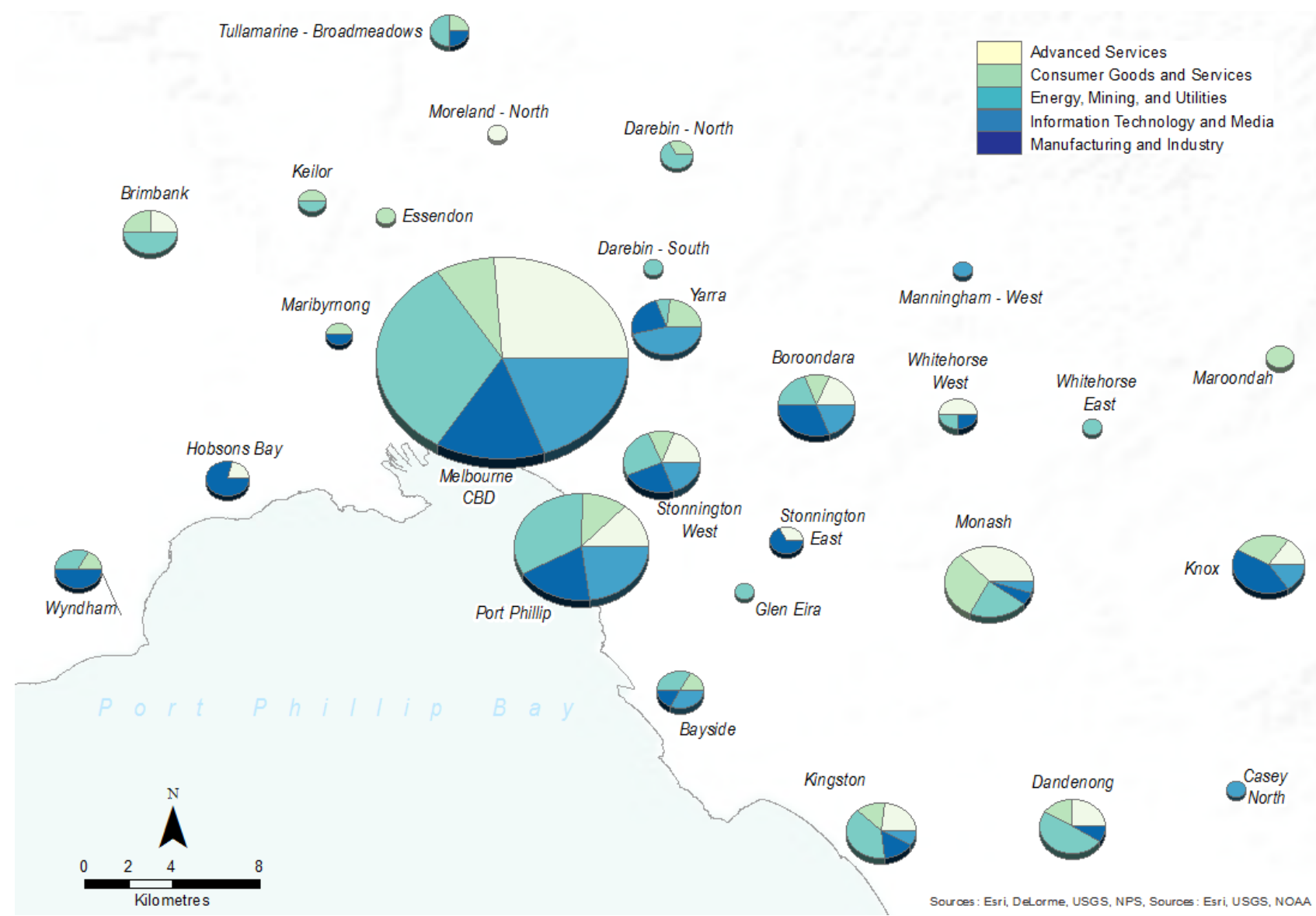

Figure 5. Melbourne Firm Headquarters and Branches 


\section{Sydney}

Australia's most populous GCCSA has 551 ASX HQ offices, primarily in materials (110), financials (85), and industrials (82). Sydney had the broadest industry sector base, with concentrations in information technology (52), real estate (51), and energy (45). As with other capital cities, HQ offices play a strong role linking Australia globally through a network of branch offices. ASX HQ offices are centralised mainly in the CBD and the adjacent inner city and North Sydney areas (Figure 5). The most centralised sectors are energy and financials, with major financial companies such as Commonwealth Bank, Westpac, Macquarie Bank and QBE all headquartered in the CBD. Most HQs outside of the CBD are concentrated in the northern 'Global Arc' of St Leonards, Chatswood and Macquarie Park (with a minor outlier beyond the latter in the specially zoned Norwest office park, Baulkham Hills, where grocery company Woolworths has its HQ). This pattern follows the locus of Sydney's professional and executive workforce residential location in northern Sydney. Planning policies have favoured these suburban centres for office development over a long period, with Chatswood nominated as a regional centre in the 1968 plan and Macquarie Park receiving its initial office development stimulus from its 1960s planning designation as an advanced technology zone (Freestone and Murphy, 1998), where global technology company Cochlear (electronic hearing devices) now has its HQ. The IT head office locations are skewed toward Macquarie Park from the CBD (Searle and Pritchard, 2005). Outside these concentrations, HQs are located in older industrial zones around the airport and in middle-western suburbs. Co-location of HQs offices with manufacturing facilities and depots in these areas explains the westerly bias of industrials and consumer staples HQs.

Branch office locations exhibit a more dispersed pattern. The main concentration is again in and near the CBD, though Parramatta - the city's strategic second designated CBD for nearly half a century - also has a significant concentration. This area lies at the centre of the western half of Sydney's population and is well-serviced by public transport. Beyond that, main branch office locations are in industrial areas across the city, with significantly more in outer industrial areas than is the case for HQ offices. 


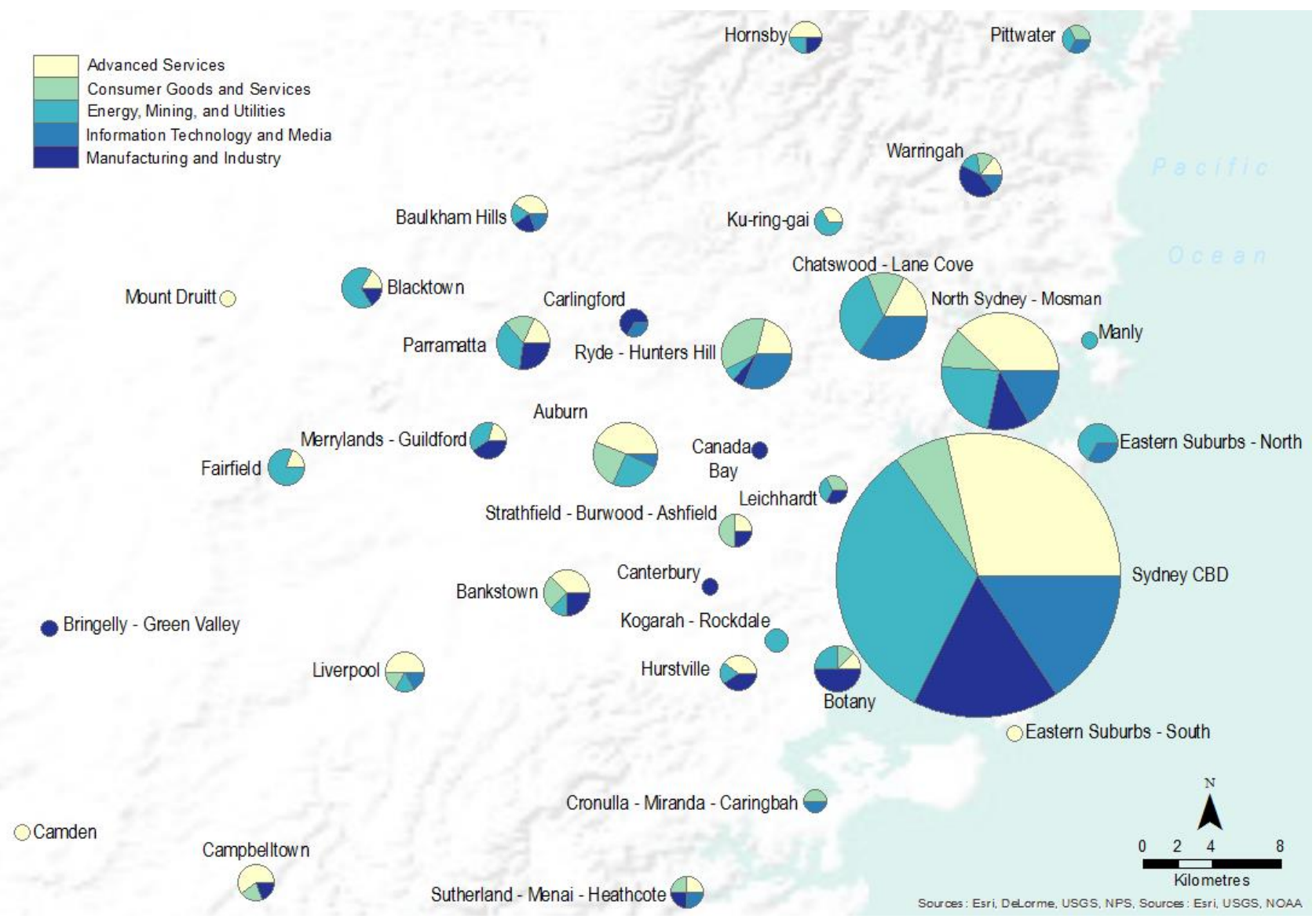

Figure 6. Sydney Firm Headquarters and Branches

\section{Conclusion}

The intra- and intra-metropolitan industrial geographies of Australia reveal the degree to which key industries and sectors are tied to global firm activities. This paper in particular has focussed on the dispersal of firms across Perth, Brisbane, Melbourne, and Sydney, finding that knowledge- and information-intensive industrial sectors are more centralised than others, through these are not necessarily more 'globalised', as past research has asserted. In the Australian case, it is in fact the resources sector (energy, materials) and related services (industrials, information technology) that are significantly globalised, and it is producer services that support the domestic activities of global firms rather than vice versa. This plays out on a smaller scale as well, with large energy, mining, and utilities firms highly centralised, which smaller firms and their branches locate in suburban corridors offering strategic advantage either through cost savings and access to human capital. In the case of manufacturing, which is somewhat more domestically oriented, outer suburban areas are more characteristic due to the locational requirements of transport and warehousing functions. 
The implication of this is a changing spatial economy, led by firms and institutions whose locational needs are determined on both local and global scales. While on a local level firms need proximity to labour and transport infrastructures, and often face-to-face access to customers, collaborators, regulators, and partner institutions, on a global scale firms need access to markets and information. Sydney's globalised firm geography is indicative of this, with far more global firms than any other city. Though the scale is considerably smaller, Perth's global connectivity is also significant - led by multinational mining and energy interests. Thus the global dimension of city connectivity extends beyond the well-rehearsed advanced producer services argument to a variety of sectors. Notwithstanding this study shows that on a local scale the requirements of each sector are somewhat similar from city to city and between firm headquarters and branches, and therefore 'global city' policy is unlikely to have the same net benefit as national policy shaping urban development and the domestic regulatory environment in ways that adapt to global conditions.

\section{References}

Bathelt, H., Malmberg, A. \& Maskell, P. (2004) 'Clusters and knowledge: local buzz, global pipelines and the process of knowledge creation', Progress in Human Geography 28(1) pp. 31-56.

Berry, M. \& Huxley, M. (1992) 'Big build: property capital, the state and urban change in Australia', International Journal of Urban and Regional Research 16(1) pp. 35-59.

Brenner, N. (2004) New State Spaces, Oxford University Press, Oxford.

Cashdm, P. (1995) 'Economic Growth and Convergence Across the Seven Colonies of Australasia: 1861-1991', Economic Record 71(2) pp. 132-144.

Connolly, E. \& Lewis, C. (2010) 'Structural change in the Australian economy', Bulletin, Reserve Bank of Australia, September Quarter, pp. 1-9.

Davison, A. (2006) 'Stuck in a cul-de-sac? Suburban history and urban sustainability in Australia', Urban Policy and Research 24(2) pp. 201-216.

Derudder, B., Taylor, P., Ni, P., De Vos, A., Hoyler, M., Hanssens, H. \& Yang, X. (2010) 'Pathways of change: Shifting connectivities in the world city network, 2000_-08', Urban Studies 47(9) pp. 1861-1877.

Department of Foreign Affairs and Trade (DFAT) (2017a) Australia's Trade at a Glance. Accessed on June 15, 2017 from http://dfat.gov.au/trade/resources/trade-at-a-glance/pages/top-goods-services.aspx (2017b) Trade in Services Australia 2015-16, Australian Government DFAT, Canberra, Australia.

Dicken, P. (1988) Global Shift: Industrial Change in a Turbulent World, Paul Chapman, London.

Dodson, J. (2005) 'Is there a spatial mismatch between housing affordability and employment opportunity in Melbourne?', AHURI Final Report 80, Brisbane: Australian Housing and Urban Research Institute, Urban Policy Program, Griffith University.

Dodson, J. (2009) 'The 'infrastructure turn' in Australian metropolitan spatial planning', International Planning Studies 14(2) pp. 109-123.

Downes, P., Hanslow, K. \& Tulip, P. (2014) The Effect of the Mining Boom on the Australian Economy, Research Discussion Paper, Reserve Bank of Australia, RDP 2014-08.

Fagan, R.H. \& Webber, M.J. (1994) Global Restructuring: The Australian Experience, Oxford University Press, USA. 
Forster, C. (2006) 'The challenge of change: Australian cities and urban planning in the new millennium', Geographical Research 44(2) pp. 173-182.

Freestone, R. \& Murphy, P. (1998) 'Metropolitan restructuring and suburban employment centers: cross-cultural perspectives on the Australian experience', Journal of the American Planning Association 64(3) pp. 286-297.

Friedmann, J. (1986) 'The World City Hypothesis', Development and Change 17(1) pp. 69-83.

Fujita, M. \& Thisse, J-F. (2013) Economics of Agglomeration: Cities, Industrial Location and Globalization (2 ${ }^{\text {nd }}$ Ed), Cambridge University Press, Cambridge UK.

Gereffi, G., Humphrey, J. \& Sturgeon, T. (2005) 'The governance of global value chains', Review of International Political Economy 12(1) pp. 78-104.

Gibson, K.D. \& Horvath, R.J. (1983) 'Global Capital and the Restructuring Crisis in Australian Manufacturing', Economic Geography 59(2) pp. 178-194.

Graham, S. \& Marvin, S. (2001) Splintering Urbanism, Routledge, London and New York.

Gurran, N. (2011) Australian Urban Land Use Planning (2nd ed.), Sydney University Press, Sydney.

Halevi, J. \& Kriesler, P. (1991) 'Australian economic growth: A structural perspective (A preliminary report)', The Economic and Labour Relations Review 2, pp. 131-142.

Hamnett, S. \& Freestone, R. (2000) The Australian Metropolis: A Planning History, Routledge, New York.

Hansen, A.L., Andersen, H.T. \& Clark, E. (2001) 'Creative Copenhagen: globalization, urban governance and social change', European Planning Studies 9(7) pp. 851-869.

Henderson, J., Dicken, P., Hess, M., Coe, N. \& Yeung, H. (2002) 'Global production networks and the analysis of economic development', Review of International Political Economy 9(3) pp. 436-464.

Holder, R. (1970) The Bank of New South Wales: A History, Volume 1, 1817-1893. Angus and Robertson, Sydney.

Hymer, S. (1976) The International Operations of National Firms: A Study of Direct Foreign Investment. PhD Thesis, Massachusetts Institute of Technology, Boston.

Le Bas, C. \& Sierra, C. (2002) “'Location versus home country advantages” in R\&D activities: some further results on multinationals' locational strategies', Research Policy 31(4) pp.589-609.

Martinus, K. \& Sigler T. (2016) 'Boomtown globalising: Perth as an internationally connected resource hub', in Biermann, S., Olaru, D. \& Paul, V. (eds) Planning Boomtown and Beyond, UWA Publishing, Perth, pp. 27-42.

Martinus, K., Sigler, T. J., Searle, G. \& Tonts, M. (2015) 'Strategic globalizing centers and sub-network geometries: A social network analysis of multi-scalar energy networks', Geoforum 64 pp. 78-89.

Massey, D. (2005) For Space, Sage, London.

O'Connor, K. (2002) 'Rethinking globalisation and urban development: The fortunes of second-ranked cities', The Australasian Journal of Regional Studies 8(3) pp. 247-260.

O’Neill, P. \& Fagan, B. (2006) 'Geographical takes on three decades of economic reform in Australia', Geographical Research 44(2) pp. 204-219.

O'Neill, P. \& McGuirk, P. (2005) 'Reterritorialisation of economies and institutions: The rise of the Sydney basin economy’, Space and Polity 9(3) pp. 283-305.

Pfister, N., Freestone, R. \& Murphy, P. (2000) 'Polycentricity or dispersion?: Changes in center employment in metropolitan Sydney, 1981 to 1996', Urban Geography 21(5) pp. 428-442.

Polèse, M. \& Shearmur, R. (2004) 'Is distance really dead? Comparing industrial location patterns over time in Canada', International Regional Science Review 27(4) pp. 431-457.

Porter, M. (2000) 'Location, competition, and economic development: local clusters in a global economy', Economic Development Quarterly 14(1) pp. 15-34.

Porter, M. \& Millar, V. (1985) 'How information gives you competitive advantage', Harvard Business Review 63(4) pp. 149-160. 
Randolph, B. \& Tice, A. (2014) 'Suburbanizing disadvantage in Australian cities: sociospatial change in an era of neoliberalism’, Journal of Urban Affairs 36(1) pp. 384-399.

Rennie-Short, J. (2004) Global Metropolitan: Globalizing Cities in a Capitalist World, Routledge, New York.

Rich, D.C. (1987) The Industrial Geography of Australia, Croom Helm, London.

Ruming, K. and Gurran, N. (2014) Australian planning system reform, Australian Planner 51(2) pp. 102-107.

Rutland, T. (2010) 'The financialization of urban redevelopment', Geography Compass 4(8) pp. 1167-1178.

Sandercock, L. (1990) Property, Politics, and Urban Planning: A History of Australian City Planning 1890-1990 (2 Ed), Transaction Publishers, Piscataway, NJ, USA.

Sassen, S. (2001) The Global City: New York, London, Tokyo, Princeton University Press, Princeton, NJ, USA.

Seamer, P. (2014) Planning the development of attractive urban spaces for business and jobs growth, Planning News 40(7) pp. 20-21.

Searle, G. (1996) Sydney as a Global City: A Discussion Paper, Department of State and Regional Development and Department of Urban Affairs and Planning, Sydney.

Searle, G. (2002) 'The demise of place equity in Sydney's economic development planning', Australian Geographer 33(3) pp. 317-336.

Searle, G. (2008) The impacts of contemporary globalisation on Australian cities, in Braun, B. \& Schuettemeyer, A. (eds) Australia Global: Australien im Prozess der Globalisierung (Australia in the Process of Globalization), Stauffenburg, Tuebingen, Germany.

Searle, G. and Bunker, R. (2010) New century Australian spatial planning: Recentralization under Labor', Planning Practice \& Research 25(4) pp. 517-529.

Searle, G. \& Pritchard, B. (2005) 'Industry clusters and Sydney's ITT sector: northern Sydney as 'Australia's Silicon Valley'?', Australian Geographer 36(2) pp. 145-169.

Shaw, K. (2013) 'Docklands Dreamings: Illusions of sustainability in the Melbourne docks redevelopment', Urban Studies 50(11) pp. 2158-2177.

Sigler, T. (2013) 'Corporate clustering in Australian cities: An analysis of the geographic distribution of ASX-listed headquarters', in Ruming K., Randolph B. \& Gurran N. (eds) SOAC 2013: 6th State of Australian Cities Conference, State of Australian Cities Research Network.

Sigler, T. \& Martinus, K. (2016) 'Extending beyond 'world cities' in World City Network (WCN) research: Urban positionality and economic linkages through the Australia-based corporate network', Environment and Planning A. DOI: https://doi.org/10.1177/0308518X16659478

Sigler, T., Searle, G., Martinus, K. \& Tonts, M. (2016) 'Metropolitan land-use patterns by economic function: a spatial analysis of firm headquarters and branch office locations in Australian cities', Urban Geography 37(3) pp. 416-435.

Smith, N. (2002) 'New globalism, new urbanism: gentrification as global urban strategy', Antipode 34(3) pp. 427-450.

Steele, W. \& Gleeson, B. (2010) 'Mind the governance gap: oil vulnerability and urban resilience in Australian cities', Australian Planner 47(4) pp. 302-310.

Stilwell, F. (2005) 'The changing city: An Australian political economy perspective', Opolis 1(2) pp. 1-16.

Taylor, P., Derudder, B., Saey, P. \& Witlox, F. (eds.) (2006) Cities in Globalization: Practices, Policies and Theories, Routledge, London and New York.

Tonts, M., Martinus, K. \& Plummer, P. (2013) 'Regional development, redistribution and the extraction of mineral resources: The Western Australian Goldfields as a resource bank', Applied Geography 45 pp. 365-374.

Tonts, M. \& Taylor, M. (2010) 'Corporate location, concentration and performance: large company headquarters in the Australian urban system', Urban Studies 47(12) pp. 2641-2664.

Tonts, M. \& Taylor, M. (2013) 'The shifting geography of corporate headquarters in Australia: a longitudinal analysis', Regional Studies 47(12) pp. 1507-1522 
Watkins, A.R. (2014) 'The spatial distribution of economic activity in Melbourne, 1971-2006', Urban Geography 35(7) pp. 1041-1065.

World Bank (2017) Exports of Goods and Services (\% of GDP). Accessed on June 152017 from http://data.worldbank.org/indicator/NE.EXP.GNFS.ZS 